\title{
PENGGUNAAN AZOIla DAN KOMPLEKS ENZIM DALAM PAKAN UNTUK MEMACU LAJU PERTUMBUHAN IKAN GURAMI
}

\author{
Kusdiarti*), Irsyaphiani Insan*), ( Wayan Subamia*), dan Hidayat Djajasewaka*)
}

\begin{abstract}
ABSTRAK
Percobaan ini bertujuan untuk mendapatkan kombinasi Azolla dan pelet berenzim pada pakan guna menunjang pertumbuhan dan sintasan benih gurami. Benih gurami ukuran $10 \mathrm{~g}$ dengan kepadatan 60 ekor dipelihara pada bak beton kapasitas $0,8 \mathrm{~m}^{3}$ selama 3,5 bulan. Sebagai perlakuan adalah kombinasi Azolla dan pelet berenzim. Pelet yang digunakan berkadar protein $40 \%$. Pakan diberikan sebanyak $5 \%$ dari bobot badan dengan frekuensi tiga kali sehari. Hasil percobaan menunjukkan terdapat perbedaan yang sangat nyata $(P<0,01)$ dalam pertumbuhan bobot individu. Perlakuan A ( $50 \%$ Azolla $+50 \%$ pelet berenzim) dan perlakuan B (60\% Azolla $+40 \%$ pelet berenzim) merupakan kombinasi pakan yang terbaik selama penelitian dengan memperoleh pertumbuhan $34,42 \mathrm{~g} / \mathrm{ind}$. dengan sintasan $76,7 \%$ dan $34,30 \mathrm{~g} / \mathrm{ind}$. dengan sintasan $66,7 \%$.
\end{abstract}

\begin{abstract}
The use of Azolla and enzyme complex to stimulate the growth of giant gouramy. By: Kusdiarti, Irsyaphiani Insan, I Wayan Subamia, and Hidayat Djajasewaka

The goal of this experiment was to obtain the best combination of Azolla and enzyme complex to support the growth and survival rate of giant gouramy fry. Sixty gouramy fries of $10 \mathrm{~g}$ average size were stocked in $0.8 \mathrm{~m}^{3}$ concrete tanks for 3.5 - month rearing period. Combinations of Azolla and pellet containing enzyme were used as treatments. The protein content in the pellet was $40 \%$. Feed was given three times daily at $5 \%$ level of body weight. The result of analysis showed there was a significant difference $(P<0.01)$ in their individual growth. During the experiment, treatment A $(50 \%$ Azolla $+50 \%$ pellet $)$ and B $(60 \%$ Azolla $+40 \%$ pellet $)$ obtained individual growth of $34.42 \mathrm{~g}$ with survival rate of $76.7 \%$ and $34.30 \mathrm{~g}$ with $66.7 \%$ respectively.
\end{abstract}

KEYWORDS: Azolla, enzyme, giant gouramy

\section{PENDAHULUAN}

Ikan gurami (Osphronemus gouramy) merupakan komoditas unggulan ikan air tawar yang banyak dibudidayakan. Kendala yang sering dihadapi dalam usaha budi daya ikan gurami adalah pertumbuhannya lambat yang terjadi pada masa pendederan. Hal ini diduga karena berbagai faktor, terutama mengenai aktivitas enzim-enzim di dalam saluran pencernaan.

Azolla sp. adalah tumbuhan air mengapung yang banyak dijumpai di perairan tergenang terutama di sawah-sawah. Azolla ini dapat digunakan untuk pakan ternak, unggas dan ikan, baik dalam bentuk segar maupun kering/tepung. Menurut Bardach et al. (1973), benih gurami ukuran $3 \mathrm{~cm}$ memakan Azolla sebagai makanan primer.

Penambahan kompleks enzim sebanyak $2 \%$ dalam pakan ikan gurami mampu meningkatkan bobot 42,9 g dari bobot awal $10 \mathrm{~g}$ selama 3,5 bulan pemeliharaan di bak beton (Insan et al., 1994). Penggunaan Azolla sebagai pengganti pakan buatan dengan perbandingan $50 \%$ pelet : $50 \%$ Azolla dalam bobot kering pada ikan gurami dengan bobot awal 10 $\mathrm{g}$ ternyata lebih bagus dibandingkan dengan yang diberi pakan $100 \%$ pelet ataupun yang diberi pakan Azolla saja (Insan et al., 1995). Hal ini berarti Azolla dapat menggantikan pakan buatan.

Agar pakan yang diberikan dapat dimanfaatkan sepenuhnya oleh ikan gurami tersebut maka salah satu usaha yang dapat dilakukan yaitu dengan jalan menambahkan enzim-enzim pencernaan melalui pakan. Penambahan enzim dalam pakan ini diharapkan dapat membantu proses pencernaan terhadap pakan yang dikonsumsi oleh ikan tersebut sesuai jenis enzimnya. Percobaan ini bertujuan untuk mengetahui kombinasi penggunaan Azolla dan kompleks enzim dalam pakan terhadap pertumbuhan ikan gurami.

\section{BAHAN DAN METODE}

Percobaan dilaksanakan di kolam percobaan Instalasi Penelitian Perikanan Air Tawar Depok dengan lama penelitian 3,5 bulan.

\footnotetext{
- Peneliti pada Balai Penelitian Perikanan Air Tawar Sukamandi
} 
Ikan gurami yang digunakan dalam percobaan ini mempunyai bobot awal berkisar 10,37-11,36 g. Ikan gurami diperoleh dari petani ikan di daerah Parung, Bogor.

Tabel 1. Komposisi bahan pakan yang digunakan dalam percobaan

Table 1. The composition of ingredient used in the experiment

\begin{tabular}{lcc}
\hline $\begin{array}{c}\text { Bahan pakan } \\
\text { (Ingredient) }\end{array}$ & $\begin{array}{c}\text { Pelet dengan enzim } \\
\text { (Feed with enzyme) }\end{array}$ & $\begin{array}{c}\text { Pelet tanpa enzim } \\
\text { (Feed without enzyme) }\end{array}$ \\
\hline Tepung ikan (Fish meal) & 38.0 & 38.0 \\
Terigu (Wheat flour) & 12.5 & 12.5 \\
Tepung kedelai (Soybean meal) & 45.0 & 47.0 \\
Campuran Mineral (Mineral Mix) & 1.0 & 1.0 \\
Campuran Vitamin (Vitamin Mix) & 1.0 & 1.0 \\
Minyak ikan (Fish oil) & 0.5 & 0.5 \\
Kompleks enzim (Enzyme complex) & 2.0 & 0.0 \\
\hline
\end{tabular}

Wadah yang digunakan untuk percobaan adalah 24 buah bak beton yang masing-masing berukuran 2 $\mathrm{m}^{2}$ dengan kedalaman air $0,4 \mathrm{~m}$ ( volume air $0,8 \mathrm{~m}^{3}$ ). Bak beton tersebut berada di luar sehingga penambahan air hanya berasal dari air hujan. Setiap bak ditebari ikan uji sebanyak 60 ekor

Perlakuan yang digunakan adalah perlakuan pakan yaitu kombinasi pakan buatan (pelet) dan pakan alami.
Pelet yang digunakan dalam percobaan ini mempunyai komposisi seperti pada Tabel 1.

Tabel2. Komposisi nutrisi pakan percobaan (\%)

Table 2. Nutrient composition of feed for experiment (\%)

Kompleks enzim yang digunakan adalah Kemyzyme (Kemin Industri) yang berisi 8 jenis enzim yaitu Pectinase, Beta Glukonase, Selulase, Alpha Amilase, Beta Amilase, Pulunase, Endoprotease dan Eksoprotease.

Sedangkan komposisi nutrisi pakan yang digunakan adalah seperti tertera pada Tabel 2.

\begin{tabular}{lccc}
\hline $\begin{array}{c}\text { Komposisi Nutrisi } \\
\text { (Nutrient Composition) }\end{array}$ & $\begin{array}{c}\text { Pelet dengan enzim } \\
\text { (Feed with enzyme) }\end{array}$ & $\begin{array}{c}\text { Pelet tanpa enzim } \\
\text { (Feed without enzyme) }\end{array}$ & Azolla \\
\hline Kadar air (Moisture) & 8.40 & 8.10 & 92.03 \\
Protein (Protein) & 40.88 & 40.35 & 19.63 \\
Lemak (Fat) & 3.58 & 3.36 & 0.18 \\
Abu (Ash) & 10.68 & 10.61 & 4.41 \\
Serat Kasar (Crude fiber) & 2.46 & 2.37 & 5.16 \\
Bahan ekstrak tanpa Nitrogen & 42.40 & 43.31 & 70.62 \\
(Nitrogen free extracts) & & & \\
\hline
\end{tabular}

Pakan buatan yang dipakai yaitu pelet tanpa enzim dan pelet dengan enzim (pelet berenzim). Sedangkan sebagai pakan alaminya adalah Azolla. Perlakuan tersebut adalah sebagai berikut:

Perlakuan A : 50\% Azolla $+50 \%$ pelet berenzim

Perlakuan B : 60\% Azolla $+40 \%$ pelet berenzim

Perlakuan C : 70\% Azolla $+30 \%$ pelet berenzim

Perlakuan D : $80 \%$ Azolla $+20 \%$ pelet berenzim

Perlakuan E : 90\% Azolla + $10 \%$ pelet berenzim

Perlakuan F : 100\% Azolla

Perlakuan G : $100 \%$ pelet berenzim

Perlakuan H : $100 \%$ pelet tanpa enzim
Pakan diberikan sebanyak $5 \%$ bobot badan/hari, dengan frekuensi pemberian pakan 3 kali sehari yaitu pada pagi, siang, dan sore hari. Penyesuaian jumlah ransum pakan dilakukan setiap selesai sampling.

Pengamatan pertumbuhan dilakukan setiap tiga minggu, pengambilan sampel dilakukan sebanyak 20 ekor/bak atau $30 \%$ dari populasi, ditimbang secara total. Penghitungan pertumbuhan menggunakan rumus Weatherley (1972) dengan rumus:

$\mathrm{W}=$ Pertumbuhan bobot mutlak rata-rata individu $(\mathrm{g})$

$\mathrm{Wt}=$ Bobot rata-rata ikan pada akhir penelitian $(\mathrm{g})$ $\mathrm{W}_{0}=$ Bobot rata-rata ikan pada awal penelitian $(\mathrm{g})$ 
Pengamatan sintasan dan mortalitas dilakukan setiap hari dengan penghitungan ikan yang mati terapung di permukaan air. Kemudian untuk keperluan penghitungan jumlah pakan, maka setiap sampling dilakukan penjumlahan. Penghitungan sintasan menggunakan rumus Effendie (1979):

$\mathrm{S}=\operatorname{Sintasan}(\%)$

$\mathrm{N}_{0}=$ Jumlah ikan pada awal penelitian (ekor)

$N_{t}=$ Jumlah ikan pada akhir penelitian (ekor)

Pengamatan kualitas air media dilakukan setiap minggu meliputi faktor fisika dan kimia air yaitu suhu air, $\mathrm{pH}, \mathrm{O}_{2}, \mathrm{CO}_{2}$, dan $\mathrm{NH}_{3}-\mathrm{N}$. Selain itu dilakukan pengamatan tambahan yaitu pengamatan aktivitas enzim protease pada saluran pencernaan ikan gurami dengan metode Elektroforesis. Rancangan percobaan yang digunakan adalah Rancangan Acak Lengkap (RAL) dengan 8 perlakuan dan masing-masing perlakuan terdiri atas 3 ulangan. Data dianalisis dengan sidik ragam berdasarkan Rancangan Acak Lengkap (Srigandono, 1980).

\section{HASIL DAN BAHASAN}

\section{Pertumbuhan dan sintasan}

Hasil pengamatan pertumbuhan selama percobaan disajikan pada Gambar 1. Dari gambar tersebut tampak pada minggu ke-3 (periode sampling I) belum memperlihatkan perbedaan pertumbuhan yang nyata relatif lebih cepat dibandingkan dengan perlakuan yang lain. Sedangkan pada ikan gurami yang diberi pakan $\mathrm{F}$ terlihat relatif tidak tumbuh.

Kemudian hasil pengamatan pertumbuhan bobot selama 3,5 bulan tertera pada Tabel 3. Pertambahan bobot untuk semua perlakuan berkisar antara 3,97 $34,42 \mathrm{~g} / \mathrm{ind}$. selama percobaan. Nilai terendah dicapai pada perlakuan F (100\% Azolla ) sedangkan nilai tertinggi diperoleh pada perlakuan A (50\% Azolla + $50 \%$ pelet berenzim) dan perlakuan B $(60 \%$ Azolla + $40 \%$ pelet berenzim). Sedangkan perlakuan D ( $80 \%$ Azolla $+20 \%$ pelet berenzim) mempunyai nilai yang sama dengan perlakuan G (100\% pelet berenzim), juga perlakuan E ( $90 \%$ Azolla $+10 \%$ pelet berenzim) tidak berbeda dengan perlakuan $\mathrm{H}$ (100\% pelet tanpa enzim).

Hasil pengamatan sintasan benih gurami selama percobaan menunjukkan bahwa dari masing-masing perlakuan tidak berbeda.

Tingginya pertumbuhan pada perlakuan A $(50 \%$ Azolla $+50 \%$ pelet berenzim) dan perlakuan B $(60 \%$ Azolla $+40 \%$ pelet berenzim) kemungkinan disebabkan adanya perbandingan kombinasi pakannya yang sesuai dengan kebutuhan ikan gurami, hal ini didukung oleh pendapat Hamid (1992) bahwa benih ikan gurami lebih menyukai pakan dengan campuran pakan hewani (tepung ikan) dan pakan

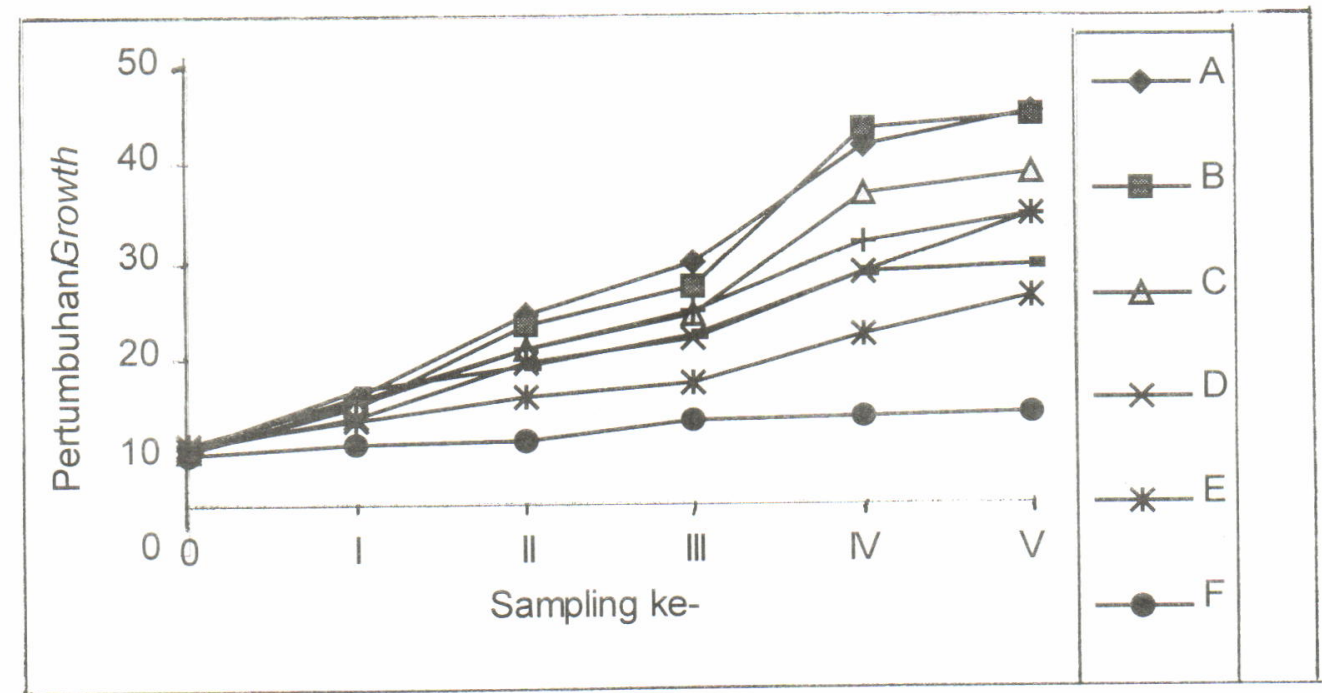

Gambar 1. Rata-rata pertumbuhan ikan gurami selama penelitian

Figure 1. The average growth of gouramy during experiment

pada masing - masing perlakuan, namun pada minggu ke-6 (periode sampling ke II) sudah menunjukkan perbedaan pertumbuhan yang nyata. Pada akhir percobaan dapat dilihat bahwa perlakuan A $(50 \%$ Azolla $+50 \%$ pelet berenzim) dan B (60\% Azolla + $40 \%$ pelet berenzim) mempunyai pertumbuhan yang nabati dalam hal ini daun sente dengan perbandingan $1: 1$.

Pada perlakuan F (100\% Azolla) ikan gurami hanya mampu mencapai bobot $14,35 \mathrm{~g}$.

Makin tinggi persentase pemberian Azolla dalam campuran pakan tersebut ternyata makin rendah 
pertumbuhannya. Hal ini diduga disebabkan oleh kurangnya daya cerna gurami terhadap Azolla.

Pada Tabel 3 juga dapat dilihat bahwa penggunaan $80 \%$ Azolla $+20 \%$ pelet berenzim (perlakuan D) ternyata mampu menyamakan atau bersaing dengan perlakuan $\mathrm{G}$ (100\% pelet berenzim), dan mempunyai pertumbuhan yang lebih baik bila dibandingkan dengan perlakuan $\mathrm{H}$ (100 pelet tanpa enzim). Hal ini berarti sudah menekan biaya operasional untuk pelet. ini ditunjang oleh pendapat De Silva \& Anderson (1955) bahwa pada usus ikan teleostei terdapat enzim aminopeptidase yaitu salah satu bentuk dari protease.Enzim protease adalah enzim yang menghidrolisis ikatan polipeptida dalam protein menjadi peptida-peptida yang sederhana dan asam amino (Hui, 1972). Dengan penambahan enzim tersebut akan mengakibatkan sel substrat yang sukar dicerna oleh enzim pencernaan hewan menjadi

Tabel 3. Pertumbuhan individu rata-rata ( $\mathrm{g}$ ) dan sintasan ikan gurami selama 3,5 bulan pemeliharaan Table 3. Average of individual growth $(\mathrm{g})$ and survival rate during 3.5 mounths culture period

\begin{tabular}{ccccc}
\hline $\begin{array}{c}\text { Perlakuan } \\
\text { (Treatment) }\end{array}$ & $\begin{array}{c}\text { Bobot awal } \\
\text { (Initial weight) } \\
\text { (g/ind.) }\end{array}$ & $\begin{array}{c}\text { Bobot akhir } \\
\text { (Final weight) } \\
\text { (g/ind.) }\end{array}$ & $\begin{array}{c}\text { Pertambahan bobot } \\
\text { (Weight gain) } \\
\text { (g/ind.) }\end{array}$ & $\begin{array}{c}\text { Sintasan } \\
\text { (Survival rate) } \\
\text { (\%) }\end{array}$ \\
\hline A & $10.89^{\mathrm{a}} \pm 0.44$ & $45.31 \pm 4.32$ & $34.42^{\mathrm{a}} \pm 3.96$ & $76.7^{\mathrm{a}}$ \\
B & $10.66^{\mathrm{a}} \pm 0.53$ & $44.96 \pm 2.42$ & $34.30^{\mathrm{a}} \pm 1.89$ & $66.7^{\mathrm{a}}$ \\
C & $10.93^{\mathrm{a}} \pm 0.49$ & $38.95 \pm 4.27$ & $28.02^{\mathrm{b}} \pm 3.96$ & $70.5^{\mathrm{a}}$ \\
D & $10.82^{\mathrm{a}} \pm 0.48$ & $34.74 \pm 1.76$ & $23.97^{\mathrm{c}} \pm 2.03$ & $73.3^{\mathrm{a}}$ \\
E & $11.28^{\mathrm{a}} \pm 0.16$ & $26.25 \pm 5.42$ & $14.97^{\mathrm{d}} \pm 5.50$ & $56.7^{\mathrm{a}}$ \\
F & $10.37^{\mathrm{a}} \pm 0.65$ & $14.35 \pm 0.58$ & $3.97^{\mathrm{a}} \pm 0.06$ & $77.2^{\mathrm{a}}$ \\
G & $11.36^{\mathrm{a}} \pm 0.06$ & $34.82 \pm 8.12$ & $23.46^{\mathrm{a}} \pm 8.18$ & $63.3^{\mathrm{a}}$ \\
H & $10.94^{\mathrm{a}} \pm 0.90$ & $29.44 \pm 1.15$ & $18.50^{\mathrm{d}} \pm 1.66$ & $74.4^{\mathrm{a}}$ \\
\hline
\end{tabular}

Note: Nilai yang diikuti dengan huruf superskrip yang tidak sama menunjukkan adanya perbedaan (Values in rows followed by different supercript are significant $(P<0.05)$ )

Juga diduga bahwa enzim yang ada di dalam pakan tersebut mampu bekerja aktif membantu pencernaan gurami, sehingga Azolla tersebut dapat dicerna lebih baik oleh ikan gurami. Menurut Zonneveld et al. (1991), untuk pencernaan unsur-unsur pakan diperlukan suatu proses hidrolisis, sedangkan proses ini berlangsung apabila terdapat enzim pencernaan. Enzim-enzim yang berperan di dalam proses pencernaan antara

struktur sel yang mudah dicerna sehingga proses pencernaan menjadi lebih baik sehingga akan menyebabkan meningkatnya pertumbuhan ikan (Wagstaff, 1989).

Hasil pengamatan parameter kualitas air selama percobaan masih cukup baik untuk kehidupan benih gurami.

Tabel 4. Aktivitas enzim protease pada saluran pencernaan ikan gurami ( $\mathrm{mg} / \mathrm{mL} / \mathrm{menit})$

Table 4. Enzyme protease activity in digestive track of gouramy $(\mathrm{mg} / \mathrm{mL} / \mathrm{menit})$

\begin{tabular}{llc}
\hline \multirow{2}{*}{ Organ } & \multicolumn{2}{c}{ Suhu (Temperature) } \\
\cline { 2 - 3 } & $30^{\circ} \mathrm{C}$ & $37^{\circ} \mathrm{C}$ \\
\hline Oesophagus & 0.462 & 0.466 \\
Gaster & 0.247 & 0.231 \\
Pancreas & 0.323 & 0.327 \\
Intestinum & 0.779 & 0.738 \\
\hline
\end{tabular}

lain karbohidrat (amilase dan selulase), Protease (pepsin, trypsin, chymotripsin, carboxypeptidase) dan enzim lipase. Enzim-enzim pencernaan tersebut terdapat di dalam organ-organ pencernaan.

Berdasarkan Tabel 4 ternyata yang paling banyak aktivitas enzim protease adalah pada intestinum. Hal

\section{KESIMPULAN}

Dari hasil penelitian benih gurami selama 3,5 bulan diketahui bahwa perlakuan A ( $50 \%$ Azolla $+50 \%$ pelet berenzim) dan perlakuan B ( $60 \%$ Azolla $+40 \%$ pelet berenzim) merupakan pakan yang terbaik dibandingkan dengan perlakuan yang lain. 


\section{DAFTARPUSTAKA}

Bardach. J.E., J.H. Ryther, and W. O. Mc Laney. 1973. Aquaculture: the Farming and Husbandry of Freshwater and Marine Organism. Wiley Interscience. A. Division of John Wiley \& Sons. 868 pp.

De Silva, $S$ and T.A. Anderson. 1955. Fish Nutrition in Aquaculture. Chapman and Hall Aquaculture series 1. Chapman and Hal, London, Glasgow, Weinhein, New York, Tokyo, Melbourne, Madras. 56 pp.

Effendi, M.I. 1979. Metode Biologi Perikanan. Yayasan Dewi Sri Bogor. 112pp.

Hamid, M.A. 1992. Kemampuan Cerna Ikan Gurami (Osphronemous gouramy Lac.) terhadap Pakan Hewani dan Pakan Nabati serta Campuran Keduanya. Skripsi. Jurusan Budidaya Perairan. Fakultas Perikanan IPB, 47 hal.

Hui, Y.H. 1972. Encyclopedia of Food Science and Technology. John Willey and Sons Inc. New York, 2:744.

Insan, I; Kusdiarti, dan I.W. Subamia. 1994. Pengaruh penambahan enzym komplek terhadap kecernaan dan pertumbuhan ikan gurami (Osphronemous gouramy). Prosiding Seminar Hasil Penelitian Perikanan Air Tawar 1992/1993. Sukamandi 24-26
Mei 1993. Lukas Dharma et al. (Eds.) Balai Penelitian Perikanan Air Tawar, Sukamandi. p. 93-97.

Insan, I; N.A. Wahyudi, dan Kusdiarti. 1995. Penggunaan Azolla sebagai pengganti pakan buatan dalam usaha pendederan ikan gurami. Tri Heru Priadi et al. (Eds.). Prosiding Seminar Hasil Penelitian Perikanan Air Tawar 1993/1994. Sukamandi 26-28 Mei 1994. Balai Penelitian Perikanan Air Tawar, Sukamandi. p. 289-294.

Ricker, W.E. 1975. Coputation and interpretation of biologies studies in biological statistics of fish population. Bull. Fish No.119 Press Board Canada. 302 pp.

Srigandono, B. 1980. Rancangan Percobaan. Fakultas Peternakan dan Perikanan Universitas Diponegoro. Semarang, 132 pp.

Wagsstaff, R.K. 1989. Enzym, General Information. Improved Digestibility of Feed by Enzyme Addition. Kemin Industries Inc. IOWA. 1 p.

Wheatherley, A.H. 1972. Growth and Ecology of Fish Population. Academic Press, London, New York. 293 pp.

Zonneveld, N.E., A. Huisman, dan J.H. Boon. 1991. Prinsip-prinsip Budidaya Ikan. PT. Gramedia, Pustaka Utama, Jakarta. 317 pp. 